\title{
Article \\ Green Synthesis of Multifunctional Carbon Dots with Antibacterial Activities
}

\author{
Arumugam Saravanan ${ }^{1}$, Moorthy Maruthapandi ${ }^{1}$, Poushali Das ${ }^{1}$, John H. T. Luong ${ }^{2}{ }^{-}$and Aharon Gedanken ${ }^{1, *}$ \\ 1 Department of Chemistry, Bar-Ilan Institute for Nanotechnology and Advanced Materials (BINA), \\ Bar-Ilan University, Ramat-Gan 52900, Israel; saran.bc94@gmail.com (A.S.); \\ lewismartin.jesus@gmail.com (M.M.); das.poushali91@gmail.com (P.D.) \\ 2 School of Chemistry, University College Cork, T12 YN60 Cork, Ireland; luongprof@gmail.com \\ * Correspondence: gedanken@mail.biu.ac.il
}

\section{check for}

updates

Citation: Saravanan, A.

Maruthapandi, M.; Das, P.; Luong, J.H.T.; Gedanken, A. Green Synthesis of Multifunctional Carbon Dots with Antibacterial Activities. Nanomaterials 2021, 11, 369. https://doi.org/ 10.3390/nano11020369

Received: 30 December 2020

Accepted: 29 January 2021

Published: 2 February 2021

Publisher's Note: MDPI stays neutral with regard to jurisdictional claims in published maps and institutional affiliations.

Copyright: (C) 2021 by the authors Licensee MDPI, Basel, Switzerland. This article is an open access article distributed under the terms and conditions of the Creative Commons Attribution (CC BY) license (https:// creativecommons.org/licenses/by/ $4.0 /)$.

\begin{abstract}
Carbon dots (CDs) were obtained from medicinal turmeric leaves (Curcuma longa) by a facile one-step hydrothermal method and evaluated for their bactericidal activities against two gramnegative; Escherichia coli, Klebsiella pneumoniae, and two gram-positive counterparts; Staphylococcus aureus, S. epidermidis. The CDs exhibited spherical shapes with a mean size of $2.6 \mathrm{~nm}$. The fluorescence spectra of CDs revealed intense fluorescence at $\lambda_{\mathrm{ex}} / \mathrm{em}=362 / 429 \mathrm{~nm}$ with a bright blue color in an aqueous solution. The CDs showed strong photostability under various environmental conditions ( $\mathrm{pH}$, salt, and UV-radiation). The complete bactericidal potency of CDs was $0.25 \mathrm{mg} / \mathrm{mL}$ for E.coli and S. aureus after $8 \mathrm{~h}$ of exposure, while for K. pneumoniae, and S. epidermidis, the CDs at $0.5 \mathrm{mg} / \mathrm{mL}$ good antibacterial effect within $8 \mathrm{~h}$ and complete eradication after $24 \mathrm{~h}$ of exposure is observed. The release of reactive oxygen species played a crucial role in the death of the bacterial cell. The present study provides a strategy for the preparation of CDs from a medicinal plant and their potential antibacterial activities against four common contagious pathogens.
\end{abstract}

Keywords: Curcuma longa; carbon dots; fluorescence; photostability; bactericidal property

\section{Introduction}

Luminescent carbon nanodots (CDs, C-dots) were accidentally discovered during the refining of single-walled carbon nanotubes in 2004 [1]. Subsequently, the preparation of fluorescent carbon nanoparticles called CDs with a dimension of $<10 \mathrm{~nm}$ was materialized [2]. CDs, a new-fangled member of the carbon nanomaterials, have good chemical and photochemical stability together with biocompatibility without intrinsic toxicity. Their unprecedented and unique properties encompass tunable emission, optical properties, biocompatibility, nontoxic, superior quantum yield, water solubility, and up-conversion photoluminescent, etc. [3-6]. There have been several efforts to apply fluorescent CDs into the field of sensors [7], optoelectronics [3], energy storage [8], light-emitting diode (LED) [9], drug delivery [10], antibacterial [11,12], bioimaging [13,14], catalysis [15], etc. To date, different synthetic routes have been identified to prepare CDs including hydrothermal [16,17], solvothermal [18,19], ultrasonication [20-22], simple heating [23,24], arc discharge [25], microwave-assisted pyrolysis [26,27], laser ablation [2,28], electrochemical $[29,30]$, etc. Initially, carbonaceous materials were utilized for the preparation of CDs resulting in lower quantum yields (QY) and limited solubilities. Considerable efforts have been taken to overcome these two drawbacks, the development of green synthetic methods for CDs has received considerable consideration. To acquire CDs through a facile, low-cost, eco-friendly method with unique properties, different natural carbon precursors have been studied such as potato [31], orange juice [32], grass [33], oats [34], Allium sativum peel [35], etc.

In recent days, the synthesis of CDs from medicinal plants have been attracted due to their cost effectiveness, availability, and natural phytocompounds. In this regard, leaves from medicinal plants such as tulsi [36], coriander leaves [37], aloe vera [38], etc. have been 
utilized for the synthesis of CDs synthesis due to their numerous phytochemicals with greater therapeutic values. CDs from medicinal plants are free from toxic chemicals and have natural capping agents. Turmeric (Curcuma longa L.) is a major herb mostly cultivated in Asia and widely used as a spice and coloring agent or food additive. It has become a popular medicinal plant worldwide, curcumin is one of the major compounds in turmeric and it functions as a drug with antioxidant, anti-bacterial, anti-fungal, anti-parasitic, antiinflammatory, anti-mutagenic, anti-carcinogenic, and detox properties [39].

Inspiring by the above biological properties, herein we extend their antibacterial properties by making CD nanoparticles (without a passivating agent) from turmeric (Curcuma longa) leaves by a one-step green synthetic pathway. The major phytochemical in turmeric leaves like curcumin, demethoxycurcumin, and bisdemethoxycurcumin serve as the carbon sources. Turmeric leaves are easily available, cheap, and can be readily converted to CDs by a simple hydrothermal technique. This work reveals a green, reliable method for the preparation of cost-effective photoluminescent CDs. Their potential applications as an emerging antimicrobial agent against four common bacterial strains are reported in the current manuscript.

\section{Experimental Section}

\subsection{Materials}

Turmeric leaves (Curcuma longa) were obtained at the green stage in the local area, Israel. Ultrapure water from Alfa Aesar (Haverhill, MA, USA) was used for the preparation of CDs. E. coli (ATCC 25922), S. aureus (ATCC 29213), K. pneumoniae (ATCC 700603), and S. epidermidis (ATCC 12228) were obtained from Dr. Banin's Lab, The Mina and Everard Goodman Faculty of Life Science, Bar Ilan University, Israel.

\subsection{Preparation of $C D s$}

CDs were successfully achieved by the one-step hydrothermal method. Briefly, $5 \mathrm{~g}$ of turmeric fresh leaves were washed, ground with $40 \mathrm{~mL}$ of ultrapure water in a mortar pestle. The leaves paste was then extracted with $20 \mathrm{~mL}$ of water. The solution was heated in a hydrothermal cell at $180{ }^{\circ} \mathrm{C}$ for $10 \mathrm{~h}$ and then continued cooling down to ambient temperature. The deep brown color extract was centrifuged at $8000 \mathrm{rpm}$ for $20 \mathrm{~min}$. The final yellow color solution was filtered and dialyzed with a cellulose syringe filter and a dialysis bag (MW cut-off $=500-1000)$. The final product was powdered using lyophilizer and dissolved in water.

\subsection{Characterization of $C D s$}

Transmission electron microscopy (TEM) image was collected with TEM- JEOL-2100 (Peabody, MA, USA), and the sample for TEM was prepared by dropping the aqueous solution of CDs onto a copper-coated TEM grid and dried at $50{ }^{\circ} \mathrm{C}$ for $2 \mathrm{~h}$. UV-Visible (Varian Cary 100 Bio Spectrophotometer) and fluorescence spectrophotometers (Varian Cary Eclipse) were used for optical properties measurement. Fourier transform infrared (FTIR) spectra were recorded using a Tensor 27 spectrometer (Bruker, Germany) ranging from 500 to $4000 \mathrm{~cm}^{-1}$. The surface charge was examined with Malvern Zetasizer NanoZS (Malvern, UK). X-ray photoelectron spectroscopy was carried out on an XPS, Nexsa spectrometer (England). The binding energies were tuned by the $\mathrm{C} 1$ s peak at $285 \mathrm{eV}$ for all elements. The ROS generation of CDs was detected on a Bruker X-band spectrometer (121 EPR 100d) using DMPO (5,5-dimethyl-1-pyrroline-N-oxide) as a spin trap. A $40 \mu \mathrm{L}$ of the CD solution was admixed with $10 \mu \mathrm{L}$ of DMPO $(0.01 \mathrm{M})$ for EPR measurement. The blank was measured using DI water without CDs.

\subsection{Photostability of CDs}

The $\mathrm{pH}$ stability was analyzed by mixing $2 \mathrm{~mL}$ of buffer at different $\mathrm{pHs}$ with $1 \mathrm{~mL}$ of CDs $(1 \mathrm{mg} / \mathrm{mL})$. For ionic strength, $2 \mathrm{~mL}$ of a solution with various concentrations of $\mathrm{NaCl}$ 
(0-1.0 M) were added with $1 \mathrm{~mL}$ of CDs $(1 \mathrm{mg} / \mathrm{mL})$. The FL emission of the solutions was recorded at an emission wavelength of $429 \mathrm{~nm}$ after $10 \mathrm{~min}$.

\subsection{Antibacterial Activity Test}

E. coli (gram-negative), K. pneumoniae (gram-negative), S. aureus (gram-positive), and S. epidermidis (gram-positive) were grown in lysogeny broth (LB) at $37^{\circ} \mathrm{C}$ overnight with agitation at $180 \mathrm{rpm}$. The resulting bacterial concentration in LB broth was adjusted to $10^{7}$ by taking absorbance at $595 \mathrm{~nm}\left(\mathrm{OD}^{595}\right)$. Typically, $500 \mu \mathrm{L}$ of bacterial cells $\left(10^{7}\right)$ in LB was mixed with $500 \mu \mathrm{L}$ of CDs with varying concentrations $(0.25,0.5$, and $1.0 \mathrm{mg} / \mathrm{mL})$ and incubated at $37^{\circ} \mathrm{C}$ for $8-24 \mathrm{~h}$ with shaking at $120 \mathrm{rpm}$. The appropriate amount of incubated bacterial solution was consecutively diluted and plated on an agar coated plate. The colonyforming unit (CFU) method was followed to calculate the rate of bacterial growth.

\section{Results and Discussion}

\subsection{Surface Morphology and Optical Properties}

The TEM image shows that CDs appeared as a spherical shape with an average mean particle size of $2.6 \mathrm{~nm}$ (Figure 1a,b). Subsequently, the particle cluster was ranging from 1.5 to $4.0 \mathrm{~nm}$ (Figure $1 \mathrm{~b}$ ) as confirmed by the particle analysis tool of image J software. The UV absorption spectra (Figure 1c) show a characteristic peak at $288 \mathrm{~nm}$, because of $\pi-\pi^{*}$ interaction of $C=C$ and $C-C$ bonds, and there is no $\mathrm{n}-\pi^{*}$ transition between $300-400 \mathrm{~nm}$. The synthesized CDs exhibited the strongest emission at $429 \mathrm{~nm}$ with excitation at $362 \mathrm{~nm}$ (Figure 1c). The CDs in aqueous solution appeared as a light yellow color under daylight (Figure 1c, inset), but exhibited bright blue luminescence when irradiated with UV light at $350 \mathrm{~nm}$. The fluorescence intensity of CDs has a maximum at $429 \mathrm{~nm}$ when photoexcited at $350 \mathrm{~nm}$, showing the typical fluorescence nature of CDs. The different emission spectra of CDs were obtained by increasing the range of excitation value from 310 to $470 \mathrm{~nm}$ with a $20 \mathrm{~nm}$ interval (Figure 1d). The excitation at $350 \mathrm{~nm}$ was preeminent to produce a bright color fluorescence at $429 \mathrm{~nm}$. Like CDs from a natural source, these CDs also exhibited excitation dependent FL behavior (Figure 1d), owning to the abundance of different sized nanoparticles and functional groups on the surface of the CDs as well as defects of CDs [40].
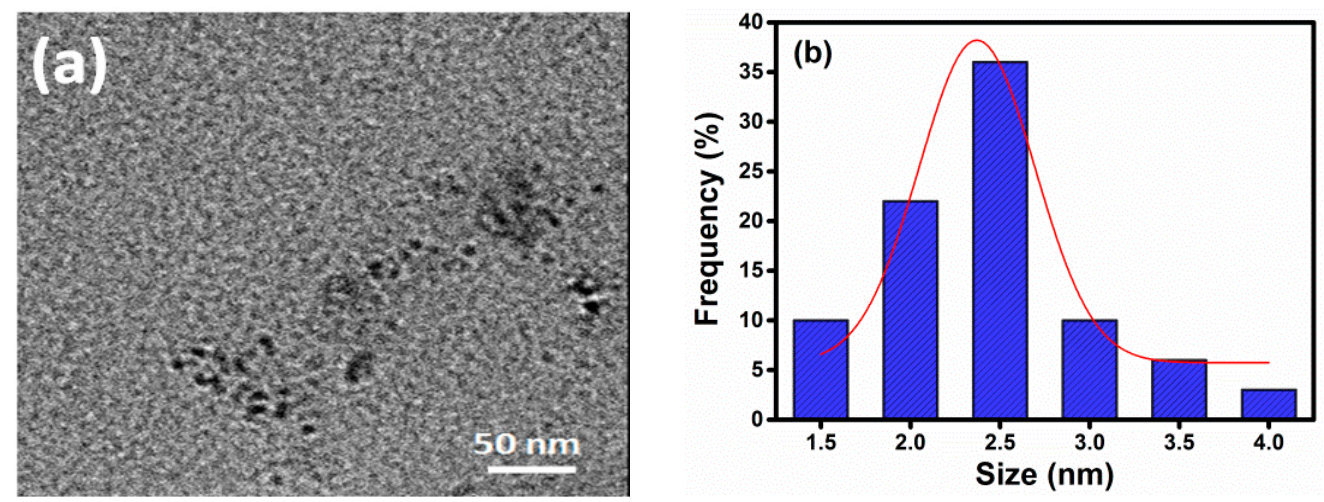

Figure 1. Cont. 

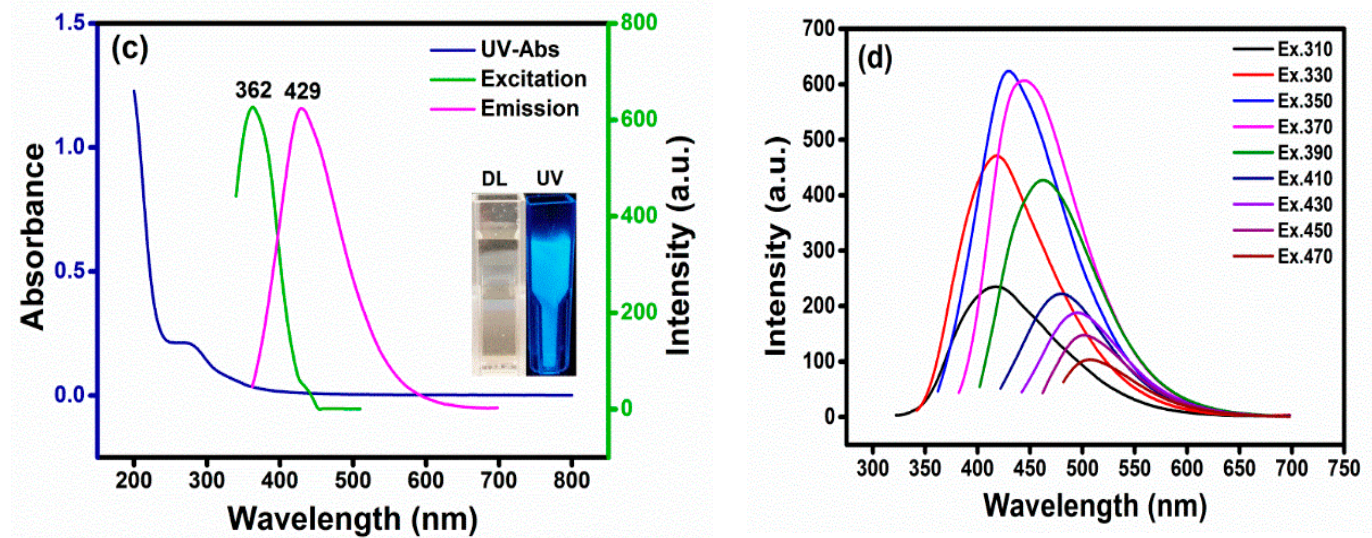

Figure 1. (a) TEM images, (b) FT-IR spectra, (c) UV, Maximum $\lambda_{\mathrm{ex}}$ and $\lambda_{\mathrm{em}}$ (Inset: photo of CDs under normal light and UV-light), and (d) fluorescence spectra of CDs at diverse excitation.

\subsection{FTIR and XPS}

FTIR spectra were employed to explore functional groups in CDs (Figure 2). The FT-IR spectra showed a strong band at 3370 is caused by O-H stretching of hydroxyl groups of phenol, this band is observed also for aliphatic $\mathrm{OH}$ whereas a moderate peak at $2951 \mathrm{~cm}^{-1}$ is assigned to C-H stretching vibration [41]. A strong peak at $1583 \mathrm{~cm}^{-1}$ reflects the $-\mathrm{C}=\mathrm{C}$ - stretching of phenolic/aromatic rings. The two peaks at $1386 \mathrm{~cm}^{-1}$ and $1153 \mathrm{~cm}^{-1}$ represent the stretching vibration of $\mathrm{C}-\mathrm{N}$ [36]. The bending and stretching vibration of $\mathrm{C}-\mathrm{O}$ bonds in the hydroxyl group is denoted at $1073 \mathrm{~cm}^{-1}$.

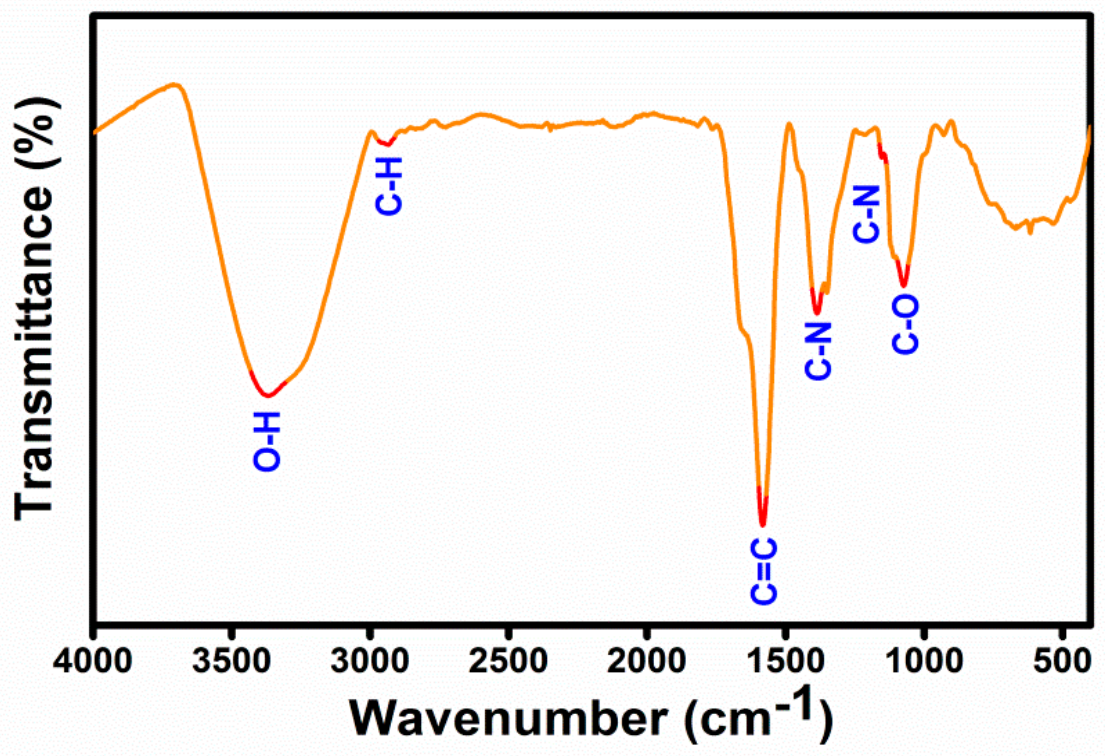

Figure 2. FTIR spectra of as-prepared CDs.

The major elemental composition of $\mathrm{CDs}$ was $\mathrm{C}=58.2, \mathrm{~N}=5.79$, and $\mathrm{O}=27.2 \%$ as determined by XPS analysis. The full XPS spectra of CDs (Figure 3a) show C1s, N1s, and $\mathrm{O} 1 \mathrm{~s}$ at 285, 400, and $532 \mathrm{eV}$, respectively. Other smaller peaks at 293 and $1069 \mathrm{eV}$ are accredited to metal elements K2p and Na1s, respectively. These trace levels of mineral elements are anticipated to stem from the plant leaves. The deconvoluted high-resolution spectra of C1s (Figure 3b) presented three distinct peaks located at 284.9, 286.3, and $288.1 \mathrm{eV}$, corresponding to $\mathrm{C}-\mathrm{C}, \mathrm{C}-\mathrm{O} / \mathrm{C}-\mathrm{N}$, and $\mathrm{C}=\mathrm{O}$ functional groups, respectively [42-44]. The two peaks at 400.1 and $402.3 \mathrm{eV}$ in high-resolution spectra of N1s, which can be attributed to the presence of $\mathrm{C}-\mathrm{N}$ and $\mathrm{N}-\mathrm{H}$ groups, respectively [45]. In the O1s high-resolution spectra, two peaks at 531.2 and $532.5 \mathrm{eV}$ are assigned to $\mathrm{C}=\mathrm{O}$ (carbonyl) and $\mathrm{C}-\mathrm{O}$ bonding [46]. 
The FTIR and XPS results suggest that the CDs have been synthesized through this facile and green hydrothermal treatment without the use of any additional chemicals/dopants. The purified CDs are hydrophilic since they have various functional groups, including carbonyl $(\mathrm{C}=\mathrm{O})$, hydroxy $(-\mathrm{OH})$, carboxylic acid $(\mathrm{O}-\mathrm{C}=\mathrm{O})$, and secondary amine $(\mathrm{N}-\mathrm{H})$ groups. These functional groups could be derived from phenolic and aromatic compounds (curcumin, demethoxycurcumin, and bisdemethoxycurcumin) in turmeric leaves [47].
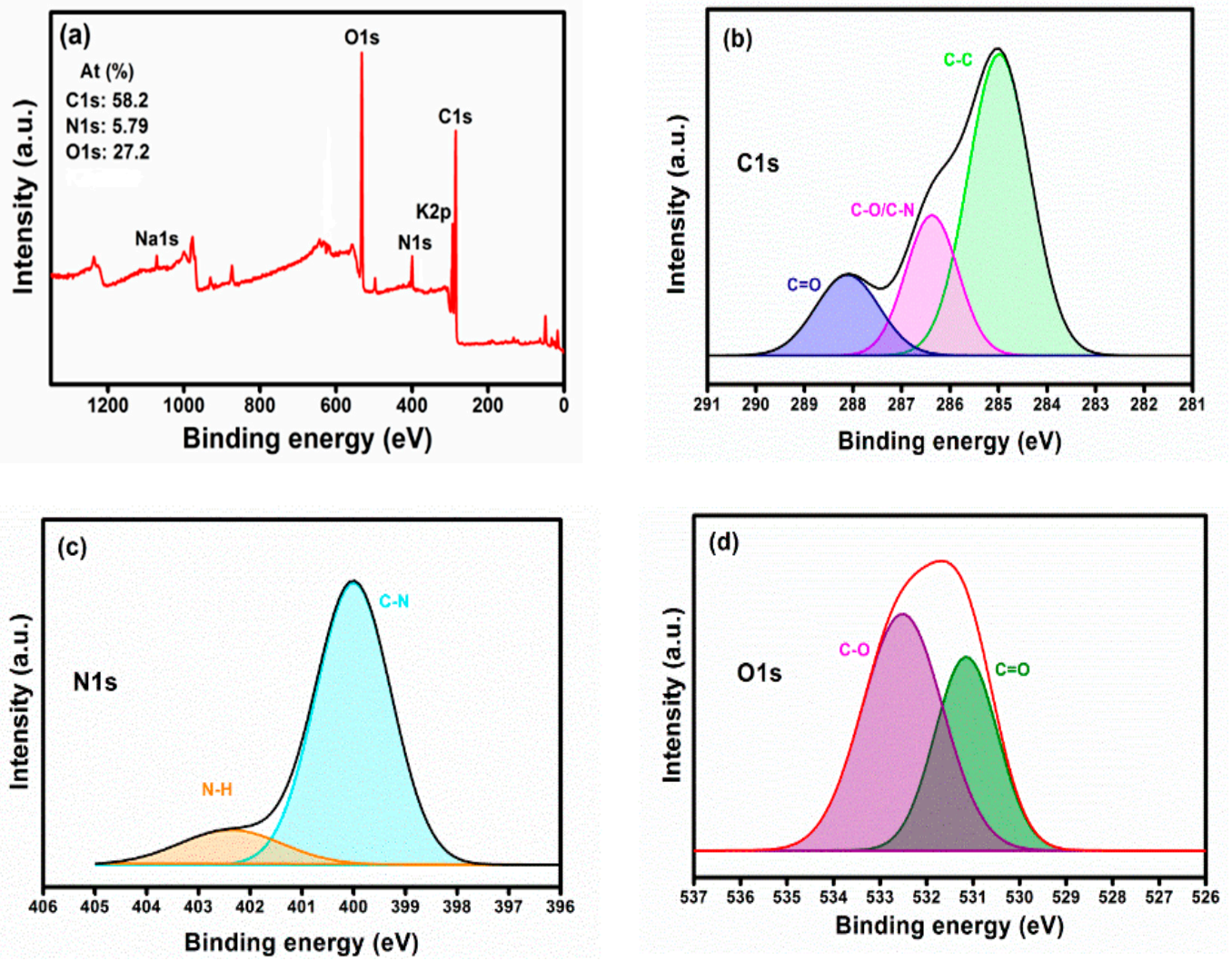

Figure 3. XPS full spectra (a), high-resolution spectra of C1s (b), N1s (c), and O1s (d) of CDs.

\subsection{The Photostability of Fluorescent $C D s$}

The photostability of $\mathrm{CDs}$ under $\mathrm{pH}$ and salt conditions is a significant property that can alter the optical and structural behavior of CDs. In this work, $\mathrm{pH}$, ionic strength, and UV-radiation on the fluorescence intensity of CDs were conducted. As depicted in Figure 4a, the emission intensity was increased significantly following the decrease in the acidic condition while a decreasing trend was observed at the extreme alkaline condition. The fluorescence emission of CDs was reduced by $57-80 \%$ in the $\mathrm{pH}=11$ to 13 due to the deprotonation of CDs. The emission intensity at pH-7-9 was optimal, considering its importance for practical bioapplications. A negligible (5\%) decline in FL emission of CDs was observed at a high concentration of $\mathrm{NaCl}(0.5 \mathrm{M})$, compared to their behavior in deionized water (Figure 4 b). Further, CDs were photostable under continuous UV radiation (a xenon arc lamp) at $\lambda_{\mathrm{ex} / \mathrm{em}}=340 / 429 \mathrm{~nm}$ for $150 \mathrm{~min}$ (Figure $4 \mathrm{c}$ ). 

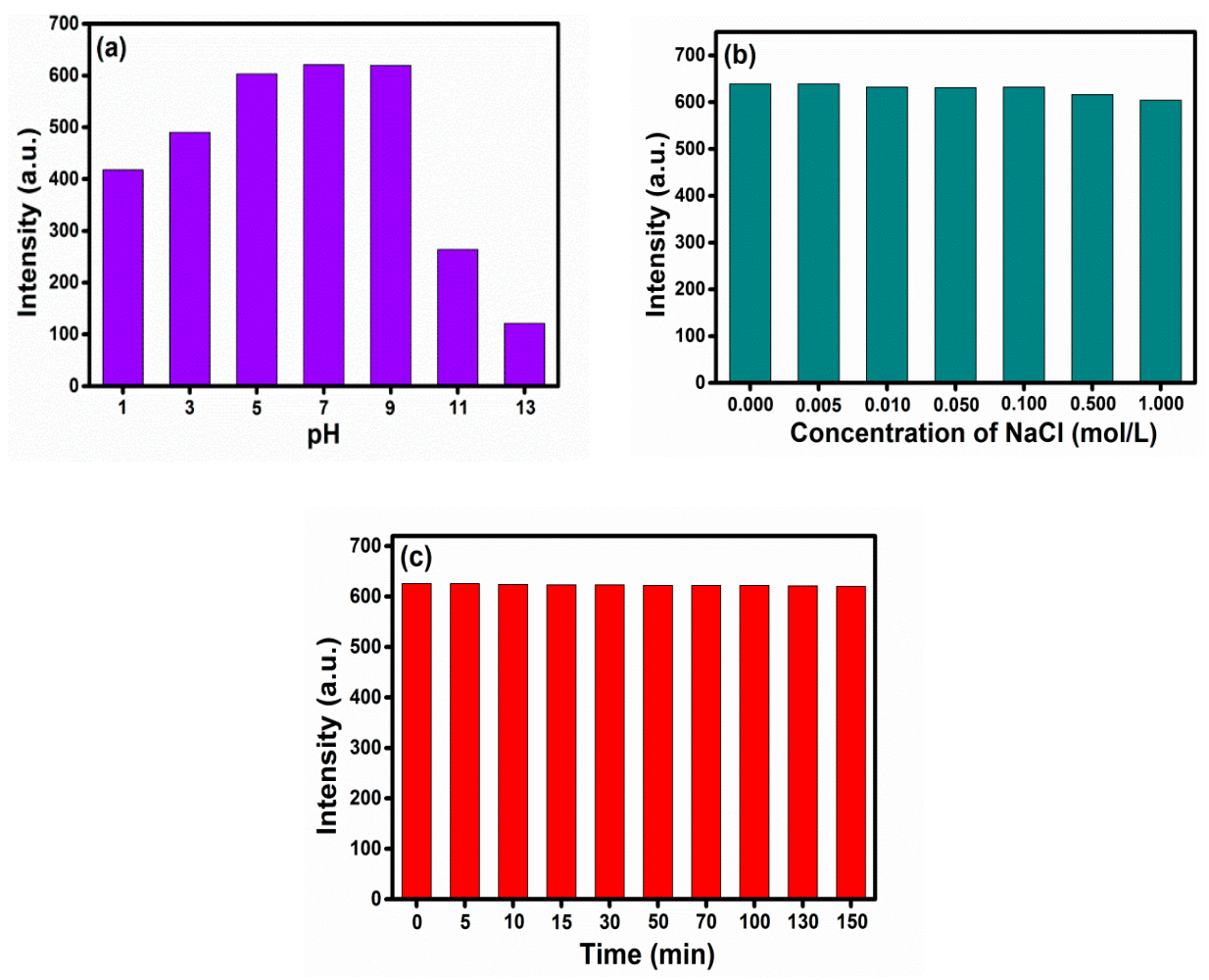

Figure 4. Photostability of CDs under (a) $\mathrm{pH}$ (b) $\mathrm{NaCl}$, and (c) UV-light.

\subsection{Antibacterial Activity}

The synthesized CDs was studied their antibacterial activity against four various gram-positive and gram-negative bacteria. The CDs were demonstrated superior for the eradication of gram-positive bacteria of $S$. aureus and S. epidermidis and gram-negative bacteria E. coli and K. pneumoniae. The minimum inhibitory concentration (MIC) is $0.25 \mathrm{mg} / \mathrm{mL}$ for E. coli and S. aureus and $0.5 \mathrm{mg} / \mathrm{mL}$ is for K. pneumoniae and S. epidermidis. The effectivity of CDs on the growth inhibition of E. coli and S. aureus within $8 \mathrm{~h}$ at $0.25 \mathrm{mg} / \mathrm{mL}$ (Figure 5a,b), compared to $0.5 \mathrm{mg} / \mathrm{mL}$ for K. pneumoniae and S. epidermidis. However, the complete eradication of bacterial cells was observed after $24 \mathrm{~h}$ incubation with $1 \mathrm{mg} / \mathrm{mL}$ of the CDs (Figure $5 \mathrm{c}, \mathrm{d}$ ). Both pathogens $E$. coli and S. aureus were completely eradicated even at low concentration $(0.25 \mathrm{mg} / \mathrm{mL})$ with 8 and $24 \mathrm{~h}$ incubation, respectively, however, the pathogens K. pneumoniae and S. epidermidis required maximum incubation time and CDs concentration $(1 \mathrm{mg} / \mathrm{mL}$ for $24 \mathrm{~h})$ to attain complete growth inhibition. The results indicated that the CDs have a rapid response to growth inhibition on E. coli and S. aureus with low concentration and incubation period. Nevertheless, K. pneumoniae and S. epidermidis were displaying a much higher incubation time for the complete eradication. In comparison to other heteroatom doped CDs reported in the literature [48-50], our synthesized CDs exhibited superior antimicrobial effects against all four pathogens without any passivation of atoms. Two major compounds, demethoxycurcumin and bisdemethoxycurcumin, are partially remained inside or on the surface of CDs, which enhance the bactericidal property of CDs. The cytotoxicity of CDs in water was evaluated by the standard MTT colorimetric assay. The cell viability assay was also performed on the PC-3 cell line to detect the inherent cytotoxicity of CDs. Figure S1 (Supplementary Materials) shows that cell survival remained greater than $95 \%$ even at $200 \mu \mathrm{g} / \mathrm{mL}$ of CDs after incubation for $24 \mathrm{~h}$. However, CDs at $500 \mu \mathrm{g} / \mathrm{mL}$ reduced $50 \%$ of cell viability after $24 \mathrm{~h}$ incubation. The antibacterial activity of this study was comparatively displayed with previous literature in Table 1 . The antibacterial effectivity of this study was comparatively displayed with the previous literature in Table 1. 

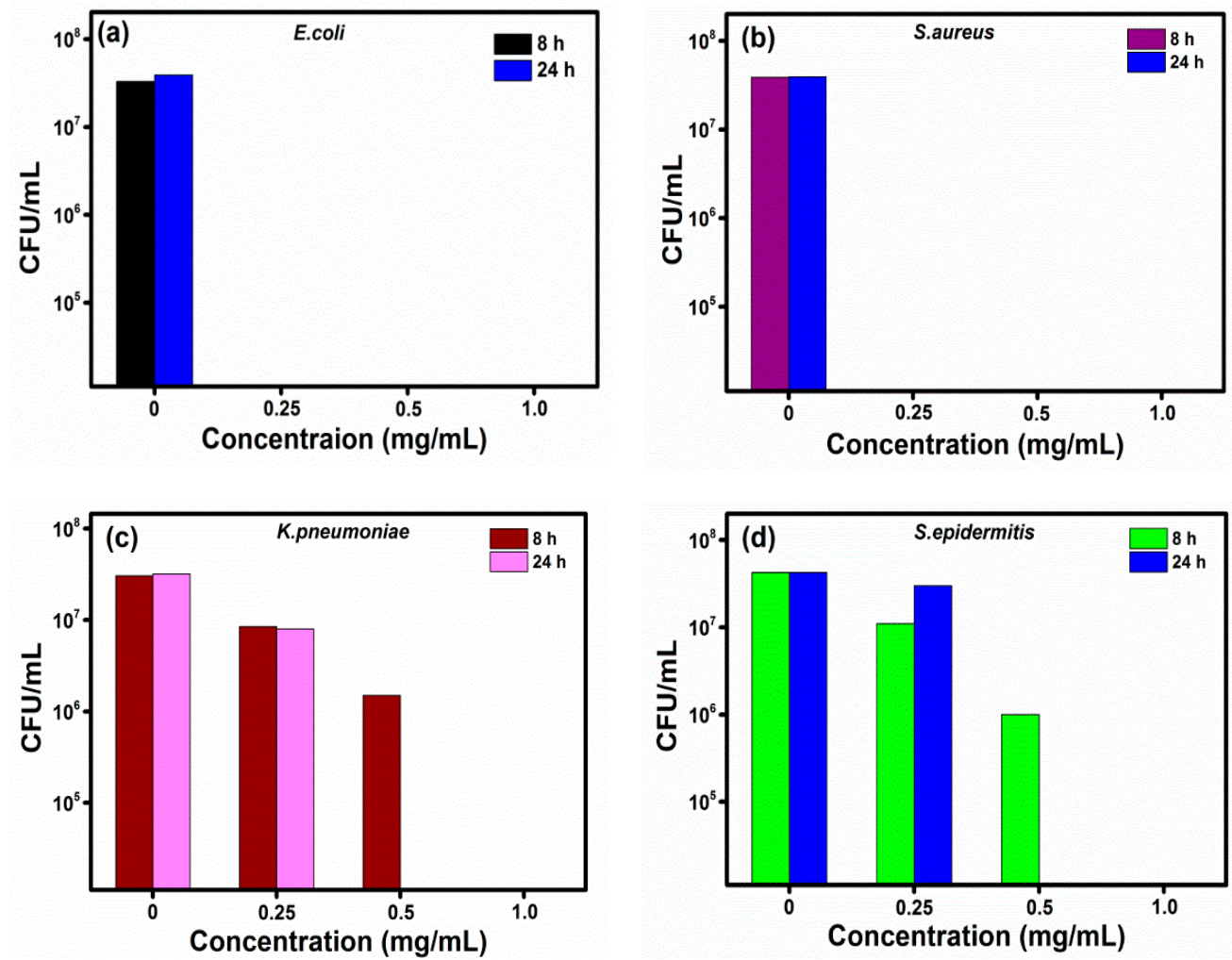

Figure 5. Bactericidal activity of CDs on (a) E. coli, (b) S. aureus, (c) K. pneumoniae, and (d) S. epidermitis.

\subsection{A postulated Mechanism}

A possible mechanism behind the observed cell death is related to reactive oxygen species (ROS). It was investigated by measuring electron paramagnetic resonance (EPR) for the samples. The EPR measures the ROS by DMPO (spin trap). The spin trap detects superoxide and hydroxyl radicals of HO-DMPO resulting in a distinct quartet peak with 1:3:3:1 signal intensity for $\mathrm{OH}$ radicals (Figure 6a). There was a 2-fold and 3.5-fold increase in the reactive oxygen species of the CDs, compared to the control. Thus, the ROS production by CDs played an important role in the eradication of the four tested bacteria. The CDs with unpaired or free electrons can react with the dissolved oxygen in the solution to produce additional ROS [51,52].
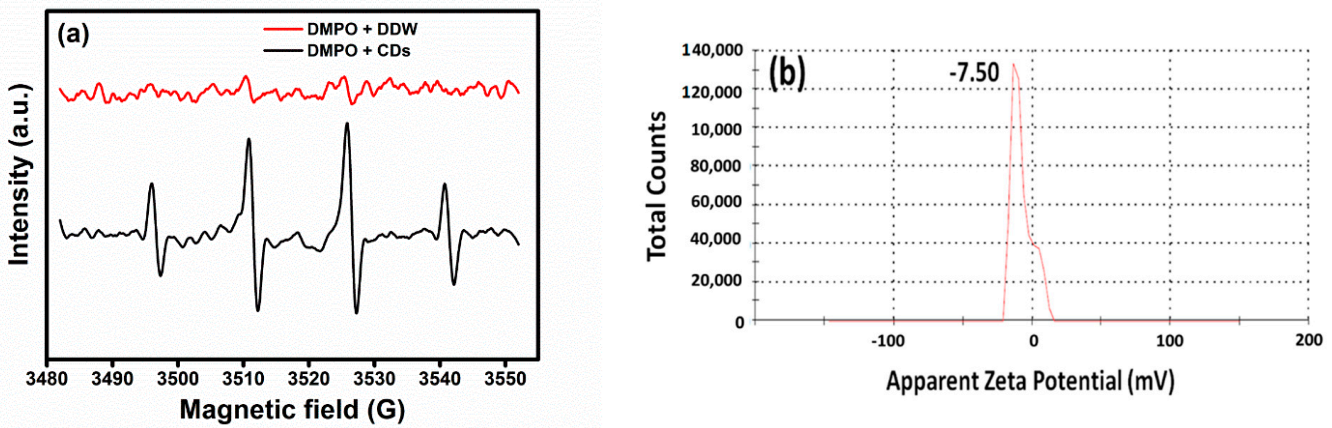

Figure 6. (a) ESR spectra and (b) surface charge of CDs. 
Table 1. Comparison table on antibacterial activity of CDs of the present study with previously reported literature.

\begin{tabular}{|c|c|c|c|c|c|c|}
\hline Type of CDs & Source & Method & Bacteria Tested & MIC/ZOI Value & $\begin{array}{l}\text { Exposure } \\
\text { Time (h) }\end{array}$ & Ref. \\
\hline $\begin{array}{l}\text { OCDs } \\
\text { TCDs }\end{array}$ & Tea leaves and milk vetch & Hydrothermal & E. coli and S. aureus & $1000 \mu \mathrm{g} / \mathrm{mL}$ & 4 & [45] \\
\hline ACDs & A. argyi leaves & Ignited & E. coli & $150 \mu \mathrm{g} / \mathrm{mL}$ & 24 & [46] \\
\hline CDs & chlorhexidine gluconate & Hydrothermal & $\begin{array}{l}\text { S. aureus } \\
\text { E.coli }\end{array}$ & $150 \mu \mathrm{g} / \mathrm{mL}$ & 24 & [49] \\
\hline Ag@CDs & $\begin{array}{c}\text { C. sativa leaf } \\
\mathrm{AgNO}_{3}\end{array}$ & Stirring & E. coli and S. aureus & $45 \mu \mathrm{g} / \mathrm{mL}$ & - & [50] \\
\hline CDs & L. inermis leaves & Hydrothermal & $\begin{array}{l}\text { E. coli } \\
\text { S. aures }\end{array}$ & $5000 \mu \mathrm{g} / \mathrm{mL}$ & 24 & [53] \\
\hline CDs & Oyster mushroom & Hydrothermal & $\begin{array}{c}\text { S. aureus, } \\
\text { K. pneumoniae }\end{array}$ & $30 \mu \mathrm{g} / \mathrm{mL}$ & 24 & [54] \\
\hline NCQDs & $\begin{array}{c}\text { D-Glucose, } \\
\text { Diethylenetriamine }\end{array}$ & Hydrothermal & S. epidermidis & $0.5 \mathrm{mg} / \mathrm{mL}$ & 18 & [55] \\
\hline CDs & Turmeric leaves leaves & Hydrothermal & $\begin{array}{c}\text { E. coli } \\
\text { S. aureus, } \\
\text { K. pneumoniae } \\
\text { S. epidermidis }\end{array}$ & $\begin{array}{c}0.25 \mathrm{mg} / \mathrm{mL} \\
0.25 \mathrm{mg} / \mathrm{mL} \\
1 \mathrm{mg} / \mathrm{mL} \\
1 \mathrm{mg} / \mathrm{mL}\end{array}$ & $\begin{array}{c}8 \\
8 \\
24 \\
24\end{array}$ & This work \\
\hline
\end{tabular}

The synthesized CDs have a negative charge on their surface due to the presence of carboxylic acid and carbonyls on the surface as confirmed by XPS spectra (Figure 3). Pristine CDs have a zeta potential of $-7 \mathrm{mV}$ (Figure 6b); thus, electrostatic interactions are unlikely a major role in the eradication of the tested bacteria. Both gram-negative and gram-positive bacteria have membranes with negative charges, however, their interaction with slightly negatively charged surfaces is still possible due to other van der Walls forces, consisting of weak London dispersion forces and stronger dipole-dipole forces [52].

\section{Conclusions}

In summary, we have synthesized multifunctional CDs from natural source turmeric (Curcuma longa) leaves without any chemicals by a facile one-step hydrothermal process. The turmeric leaves are easily available, making the production of the CDs cost-effective. They have various secondary metabolites and served as a carbon source for preparing CDs. The CDs exhibited superior photostability under various environmental conditions. CDs can eradicate four different types of gram-negative and gram-positive bacteria. The bactericidal property of CDs on both E. coli and S. aureus was at low concentration and incubation time $(0.25 \mathrm{mg} / \mathrm{mL}$ for $8 \mathrm{~h})$. However, K. pneumoniae and S. epidermitis required $1 \mathrm{mg} / \mathrm{mL}$ and $24 \mathrm{~h}$ incubation to achieve complete growth inhibition. Our finding may open a gateway to synthesize naturally derived CDs from turmeric leaves towards a new antimicrobial agent.

Supplementary Materials: The following are available online at https:/ /www.mdpi.com/2079-4991/ 11/2/369/s1, Figure S1: Cell viability of PC-3 cells after $24 \mathrm{~h}$ incubation with various concentrations of CDs.

Author Contributions: Material characterization and original draft preparation, A.S.; Studies on the antibacterial activity, M.M.; Formal analysis and software, P.D.; Review and editing, J.H.T.L.; Supervision, A.G. All authors have read and agreed to the published version of the manuscript.

Funding: This work receives no funding.

Institutional Review Board Statement: Not applicable.

Informed Consent Statement: Not applicable.

Data Availability Statement: Data presented in this study are available by requesting from the corresponding author. 
Conflicts of Interest: The authors declare no conflict of interest.

\section{References}

1. Xu, X.; Ray, R.; Gu, Y.; Ploehn, H.J.; Gearheart, L.; Raker, K.; Scrivens, W.A. Electrophoretic analysis and purification of fluorescent single-walled carbon nanotube fragments. J. Am. Chem. Soc. 2004, 126, 12736-12737. [CrossRef] [PubMed]

2. Sun, Y.P.; Zhou, B.; Lin, Y.; Wang, W.; Fernando, K.S.; Pathak, P.; Meziani, M.J.; Harruff, B.A.; Wang, X.; Wang, H.; et al. Quantumsized carbon dots for bright and colorful photoluminescence. J. Am. Chem. Soc. 2006, 128, 7756-7757. [CrossRef] [PubMed]

3. Baker, S.N.; Baker, G.A. Luminescent carbon nanodots: Emergent nanolights. Angew. Chem. Int. Ed. 2010, 49, 6726-6744. [CrossRef] [PubMed]

4. Das, P.; Ganguly, S.; Banerjee, S.; Das, N.C. Graphene based emergent nanolights: A short review on the synthesis, properties and application. Res. Chem. Intermed. 2019, 45, 3823-3853. [CrossRef]

5. Ganguly, S.; Das, P.; Banerjee, S.; Das, N.C. Advancement in science and technology of carbon dot-polymer hybrid composites: A review. Funct. Compos. Struct. 2019, 1, 022001. [CrossRef]

6. Moorthy, M.; Kumar, V.B.; Porat, Z.E.; Gedanken, A. Novel polymerization of aniline and pyrrole by carbon dots. New J. Chem. 2018, 42, 535-540. [CrossRef]

7. Das, P.; Maruthapandi, M.; Saravanan, A.; Natan, M.; Jacobi, G.; Banin, E.; Gedanken, A. Carbon dots for heavy-metal sensing, pH-sensitive cargo delivery, and antibacterial applications. ACS Appl. Nano Mater. 2020, 3, 11777-11790. [CrossRef]

8. Hoang, V.C.; Dave, K.; Gomes, V.G. Carbon quantum dot-based composites for energy storage and electrocatalysis: Mechanism, applications and future prospects. Nano Energy 2019, 66, 104093. [CrossRef]

9. Zhang, X.; Zhang, Y.; Wang, Y.; Kalytchuk, S.; Kershaw, S.V.; Wang, Y.; Wang, P.; Zhang, T.; Zhao, Y.; Zhang, H.; et al. Colorswitchable electroluminescence of carbon dot light-emitting diodes. ACS Nano 2013, 7, 11234-11241. [CrossRef]

10. Ganguly, S.; Das, P.; Itzhaki, E.; Hadad, E.; Gedanken, A.; Margel, S. Microwave-synthesized polysaccharide-derived carbon dots as therapeutic cargoes and toughening agents for elastomeric gels. ACS Appl. Mater. Interfaces 2020, 12, 51940-51951. [CrossRef]

11. Saravanan, A.; Maruthapandi, M.; Das, P.; Ganguly, S.; Margel, S.; Luong, J.H.T.; Gedanken, A. Applications of N-doped carbon dots as antimicrobial agents, antibiotic carriers, and selective fluorescent probes for nitro explosives. ACS Appl. Bio Mater. 2020, 3, 8023-8031. [CrossRef]

12. Das, P.; Ganguly, S.; Bose, M.; Ray, D.; Ghosh, S.; Mondal, S.; Aswal, V.K.; Das, A.K.; Banerjee, S.; Das, N.C. Surface quaternized nanosensor as a one-arrow-two-hawks approach for fluorescence turn "on-off-on" bifunctional sensing and antibacterial activity. New J. Chem. 2019, 43, 6205-6219. [CrossRef]

13. Feng, T.; Ai, X.; An, G.; Yang, P.; Zhao, Y. Charge-convertible carbon dots for imaging-guided drug delivery with enhanced in vivo cancer therapeutic efficiency. ACS Nano 2016, 10, 4410-4420. [CrossRef] [PubMed]

14. Das, P.; Bose, M.; Ganguly, S.; Mondal, S.; Das, A.K.; Banerjee, S.; Das, N.C. Green approach to photoluminescent carbon dots for imaging of gram-negative bacteria Escherichia coli. Nanotechnology 2017, 28, 195501. [CrossRef] [PubMed]

15. Wu, W.; Zhan, L.; Ohkubo, K.; Yamada, Y.; Wu, M.; Fukuzumi, S. Photocatalytic H2 evolution from NADH with carbon quantum dots/Pt and 2-phenyl-4-(1-naphthyl) quinolinium ion. J. Photochem. Photobiol. B Biol. 2015, 152, 63-70. [CrossRef] [PubMed]

16. Maruthapandi, M.; Sharma, K.; Luong, J.H.T.; Gedanken, A. Antibacterial activities of microwave-assisted synthesized polypyrrole/chitosan and poly (pyrrole-N-(1-naphthyl) ethylenediamine) stimulated by C-dots. Carbohydr. Polym. 2020, $243,116474$. [CrossRef] [PubMed]

17. Das, P.; Maity, P.P.; Ganguly, S.; Ghosh, S.; Baral, J.; Bose, M.; Choudhary, S.; Gangopadhyay, S.; Dhara, S.; Das, A.K.; et al. Biocompatible carbon dots derived from $\mathrm{K}$-carrageenan and phenyl boronic acid for dual modality sensing platform of sugar and its anti-diabetic drug release behavior. Int. J. Biol. Macromol. 2019, 132, 316-329.

18. Qian, Z.; Ma, J.; Shan, X.; Feng, H.; Shao, L.; Chen, J. Highly luminescent N-doped carbon quantum dots as an effective multifunctional fluorescence sensing platform. Chem. Eur. J. 2014, 20, 2254-2263. [CrossRef]

19. Ku, K.; Lee, S.W.; Park, J.; Kim, N.; Chung, H.; Han, C.H.; Kim, W. Large-scale solvothermal synthesis of fluorescent carbon nanoparticles. Nanotechnology 2014, 25, 395601. [CrossRef]

20. Maruthapandi, M.; Kumar, V.B.; Levine, M.; Gedanken, A. Fabrication of poly (4, 4'-oxybisbenzenamine) and its conjugated copolymers initiated by easily accessible carbon dots. Eur. Polym. J. 2018, 109, 153-161. [CrossRef]

21. Maruthapandi, M.; Gedanken, A. A short report on the polymerization of pyrrole and its copolymers by sonochemical synthesis of fluorescent carbon dots. Polymers 2019, 11, 1240. [CrossRef] [PubMed]

22. Das, P.; Ganguly, S.; Maity, P.P.; Bose, M.; Mondal, S.; Dhara, S.; Das, A.K.; Banerjee, S.; Das, N.C. Waste chimney oil to nanolights: A low cost chemosensor for tracer metal detection in practical field and its polymer composite for multidimensional activity. $J$. Photochem. Photobiol. B Biol. 2018, 180, 56-67. [CrossRef] [PubMed]

23. Ganguly, S.; Das, P.; Bose, M.; Das, T.K.; Mondal, S.; Das, A.K.; Das, N.C. Sonochemical green reduction to prepare Ag nanoparticles decorated graphene sheets for catalytic performance and antibacterial application. Ultrason. Sonochem. 2017, 39, 577-588. [CrossRef] [PubMed]

24. Ganguly, S.; Das, P.; Bose, M.; Mondal, S.; Das, A.K.; Das, N.C. Strongly blue-luminescent N-doped carbogenic dots as a tracer metal sensing probe in aqueous medium and its potential activity towards in situ Ag-nanoparticle synthesis. Sens. Actuators B Chem. 2017, 252, 735-746. [CrossRef] 
25. Xu, J.; Sahu, S.; Cao, L.; Anilkumar, P.; Tackett, K.N.; Qian, H.; Bunker, C.E.; Guliants, E.A.; Parenzan, A.; Sun, Y.P. Carbon nanoparticles as chromophores for photon harvesting and photoconversion. ChemPhysChem 2011, 12, 3604-3608. [CrossRef]

26. Liu, H.; He, Z.; Jiang, L.P.; Zhu, J.J. Microwave-assisted synthesis of wavelength-tunable photoluminescent carbon nanodots and their potential applications. ACS Appl. Mater. Interfaces 2015, 7, 4913-4920. [CrossRef]

27. Das, P.; Ganguly, S.; Mondal, S.; Ghorai, U.K.; Maity, P.P.; Choudhary, S.; Gangopadhyay, S.; Dhara, S.; Banerjee, S.; Das, N.C. Dual doped biocompatible multicolor luminescent carbon dots for bio labeling, UV-active marker and fluorescent polymer composite. Luminescence 2018, 33, 1136-1145. [CrossRef]

28. Yang, S.T.; Cao, L.; Luo, P.G.; Lu, F.; Wang, X.; Wang, H.; Meziani, M.J.; Liu, Y.; Qi, G.; Sun, Y.P. Carbon dots for optical imaging in vivo. J. Am. Chem. Soc. 2009, 131, 11308-11309. [CrossRef]

29. Deng, J.; Lu, Q.; Mi, N.; Li, H.; Liu, M.; Xu, M.; Tan, L.; Xie, Q.; Zhang, Y.; Yao, S. Electrochemical synthesis of carbon nanodots directly from alcohols. Chem. Eur. J. 2014, 20, 4993-4999. [CrossRef]

30. Bao, L.; Zhang, Z.L.; Tian, Z.Q.; Zhang, L.; Liu, C.; Lin, Y.; Qi, B.; Pang, D.W. Electrochemical tuning of luminescent carbon nanodots: From preparation to luminescence mechanism. Adv. Mater. 2011, 23, 5801-5806. [CrossRef]

31. Mehta, V.N.; Jha, S.; Singhal, R.K.; Kailasa, S.K. Preparation of multicolor emitting carbon dots for HeLa cell imaging. New J. Chem. 2014, 38, 6152-6160. [CrossRef]

32. Sahu, S.; Behera, B.; Maiti, T.K.; Mohapatra, S. Simple one-step synthesis of highly luminescent carbon dots from orange juice: Application as excellent bio-imaging agents. Chem Comm 2012, 48, 8835-8837. [CrossRef] [PubMed]

33. Liu, S.; Tian, J.; Wang, L.; Zhang, Y.; Qin, X.; Luo, Y.; Asiri, A.M.; Al-Youbi, A.O.; Sun, X. Hydrothermal treatment of grass: A low-cost, green route to nitrogen-doped, carbon-rich, photoluminescent polymer nanodots as an effective fluorescent sensing platform for label-free detection of Cu (II) ions. Adv. Mater. 2012, 24, 2037-2041. [CrossRef] [PubMed]

34. Shi, L.; Li, X.; Li, Y.; Wen, X.; Li, J.; Choi, M.M.; Dong, C.; Shuang, S. Naked oats-derived dual-emission carbon nanodots for ratiometric sensing and cellular imaging. Sens. Actuators B Chem. 2015, 210, 533-541. [CrossRef]

35. Das, P.; Ganguly, S.; Maity, P.P.; Srivastava, H.K.; Bose, M.; Dhara, S.; Bandyopadhyay, S.; Das, A.K.; Banerjee, S.; Das, N.C. Converting waste Allium sativum peel to nitrogen and sulphur co-doped photoluminescence carbon dots for solar conversion, cell labeling, and photobleaching diligences: A path from discarded waste to value-added products. J. Photochem. Photobiol. B Biol. 2019, 197, 111545. [CrossRef]

36. Bhatt, S.; Bhatt, M.; Kumar, A.; Vyas, G.; Gajaria, T.; Paul, P. Green route for synthesis of multifunctional fluorescent carbon dots from Tulsi leaves and its application as Cr (VI) sensors, bio-imaging and patterning agents. Colloids Surf. B Biointerfaces 2018, 167, 126-133. [CrossRef]

37. Sachdev, A.; Gopinath, P. Green synthesis of multifunctional carbon dots from coriander leaves and their potential application as antioxidants, sensors and bioimaging agents. Analyst 2015, 140, 4260-4269. [CrossRef]

38. Devi, P.; Thakur, A.; Bhardwaj, S.K.; Saini, S.; Rajput, P.; Kumar, P. Metal ion sensing and light activated antimicrobial activity of aloe-vera derived carbon dots. J. Mater. Sci. Mater. Electron. 2018, 29, 17254-17261. [CrossRef]

39. Akamine, H.; Hossain, M.A.; Ishimine, Y.; Yogi, K.; Hokama, K.; Iraha, Y.; Aniya, Y. Effects of application of N, P and K alone or in combination on growth, yield and curcumin content of turmeric (Curcuma longa L.). Plant Prod. Sci. 2007, 10, 151-154. [CrossRef]

40. Peng, J.; Gao, W.; Gupta, B.K.; Liu, Z.; Romero-Aburto, R.; Ge, L.; Song, L.; Alemany, L.B.; Zhan, X.; Gao, G.; et al. Graphene quantum dots derived from carbon fibers. Nano Lett. 2012, 12, 844-849. [CrossRef]

41. Vasimalai, N.; Vilas-Boas, V.; Gallo, J.; de Fátima Cerqueira, M.; Menéndez-Miranda, M.; Costa-Fernández, J.M.; Diéguez, L.; Espiña, B.; Fernández-Argüelles, M.T. Green synthesis of fluorescent carbon dots from spices for in vitro imaging and tumour cell growth inhibition. Beilstein J. Nanotechnol. 2018, 9, 530-544. [CrossRef] [PubMed]

42. Zhu, L.; Yin, Y.; Wang, C.F.; Chen, S. Plant leaf-derived fluorescent carbon dots for sensing, patterning and coding. J. Mater. Chem. C 2013, 1, 4925-4932. [CrossRef]

43. Huang, G.; Chen, X.; Wang, C.; Zheng, H.; Huang, Z.; Chen, D.; Xie, H. Photoluminescent carbon dots derived from sugarcane molasses: Synthesis, properties, and applications. RSC Adv. 2017, 7, 47840-47847. [CrossRef]

44. Pramanik, S.; Chatterjee, S.; Kumar, G.S.; Devi, P.S. Egg-shell derived carbon dots for base pair selective DNA binding and recognition. Phys. Chem. Chem. Phys. 2018, 20, 20476-20488. [CrossRef] [PubMed]

45. Ma, Y.; Zhang, M.; Wang, H.; Wang, B.; Huang, H.; Liu, Y.; Kang, Z. N-doped carbon dots derived from leaves with low toxicity via damaging cytomembrane for broad-spectrum antibacterial activity. Mater. Today Commun. 2020, 101222. [CrossRef]

46. Wang, H.; Zhang, M.; Ma, Y.; Wang, B.; Shao, M.; Huang, H.; Liu, Y.; Kang, Z. Selective inactivation of Gram-negative bacteria by carbon dots derived from natural biomass: Artemisia argyi leaves. J. Mater. Chem. B 2020, 8, 2666-2672. [CrossRef] [PubMed]

47. Niranjan, A.; Prakash, D. Chemical constituents and biological activities of turmeric (Curcuma longa L.) - A review. J. Food Sci. Technol. 2008, 45, 109.

48. Li, H.; Huang, J.; Song, Y.; Zhang, M.; Wang, H.; Lu, F.; Huang, H.; Liu, Y.; Dai, X.; Gu, Z.; et al. Degradable carbon dots with broad-spectrum antibacterial activity. ACS Appl. Mater. Interfaces 2018, 10, 26936-26946. [CrossRef]

49. Sun, B.; Wu, F.; Zhang, Q.; Chu, X.; Wang, Z.; Huang, X.; Li, J.; Yao, C.; Zhou, N.; Shen, J. Insight into the effect of particle size distribution differences on the antibacterial activity of carbon dots. J. Colloid Interface Sci. 2020, 584, 505-519. [CrossRef]

50. Raina, S.; Thakur, A.; Sharma, A.; Pooja, D.; Minhas, A.P. Bactericidal activity of Cannabis sativa phytochemicals from leaf extract and their derived Carbon Dots and Ag@ Carbon Dots. Mater. Lett. 2020, 262, 127122. [CrossRef] 
51. Maruthapandi, M.; Saravanan, A.; Das, P.; Natan, M.; Jacobi, G.; Banin, E.; Luong, J.H.T.; Gedanken, A. Antimicrobial activities of Zn-doped $\mathrm{CuO}$ microparticles decorated on polydopamine against sensitive and antibiotic-resistant bacteria. ACS Appl. Polym. Mater. 2020, 2, 5878-5888. [CrossRef]

52. Maruthapandi, M.; Saravanan, A.; Luong, J.H.T.; Gedanken, A. Antimicrobial properties of polyaniline and polypyrrole decorated with zinc-doped copper oxide microparticles. Polymers 2020, 12, 1286. [CrossRef] [PubMed]

53. Shahshahanipour, M.; Rezaei, B.; Ensafi, A.A.; Etemadifar, Z. An ancient plant for the synthesis of a novel carbon dot and its applications as an antibacterial agent and probe for sensing of an anti-cancer drug. Mater. Sci. Eng. C 2019, 98, 826-833. [CrossRef] [PubMed]

54. Boobalan, T.; Sethupathi, M.; Sengottuvelan, N.; Kumar, P.; Zoltán Gulyás, B.; Padmanabhan, P.; Tamil Selvan, S.; Arun, A. Mushroom-derived carbon dots for toxic metal ion detection and as antibacterial and anticancer agents. ACS Appl. Nano Mater. 2020, 3, 5910-5919. [CrossRef]

55. Zhao, C.; Wang, X.; Wu, L.; Wu, W.; Zheng, Y.; Lin, L.; Weng, S.; Lin, X. Nitrogen-doped carbon quantum dots as an antimicrobial agent against Staphylococcus for the treatment of infected wounds. Colloids Surf. B Biointerfaces 2019, 179, 17-27. [CrossRef] 